\title{
Nuevos avances en la carbonatación del cemento aluminoso. Hidrólisis alcalina
}

\author{
New advances in the carbonation of aluminous cement. Alkaline \\ hydrolisis
}

\author{
L.FERNÁNDEZ-CARRASCO,F.PUERTAS,M.T.BLANCO-VARELAy T.VÁZQUEZ
}

Instituto de Ciencias de la Construcción Eduardo Torroja (CSIC)

Fecha de recepción: 2-X-98

Fecha de aceptación: 29-XII-98

ESPAÑA

\begin{abstract}
RESUMEN
Se realiza un estudio del proceso de carbonatación del cemento aluminoso en presencia de una concentración elevada de álcalis.

En el presente trabajo se demuestra la formación, en las muestras estudiadas, de un compuesto cuya fórmula es cercana a $\mathrm{K}_{4} \mathrm{Al}_{6}\left(\mathrm{CO}_{3}\right)_{11-\mathrm{x}}(\mathrm{OH})_{2 x}\left(\mathrm{H}_{2} \mathrm{O}\right)_{y}$

La carbonatación del cemento aluminoso en presencia de álcalis tiene lugar, al menos, en dos etapas. La primera de ellas da lugar a la formación de un carbonato de aluminio y potasio hidratado junto a $\mathrm{CaCO}_{3}$. Posteriormente este carbonato de aluminio y potasio hidratado evoluciona hacia la formación de hidróxido de aluminio.
\end{abstract}

\section{SUMMARY}

The carbonation process of aluminous cement in presence of high alkali content is studied.

In this work, the formation of a compound which formula is close to $\mathrm{K}_{1} \mathrm{Al}_{6}\left(\mathrm{CO}_{3}\right)_{11-x}(\mathrm{OH})_{2 x}\left(\mathrm{H}_{2} \mathrm{O}\right)_{y}$ is shown for the studies samples.

The aluminous cement carbonation in alkali presence take place, at least, in two stages. In a first stage the aluminium and potassium carbonate hydrate joint to $\mathrm{CaCO}_{3}$ is formed. Later, that aluminium potassium carbonate hydrate is developed toward the aluminium hydroxide formation.

\section{INTRODUCCIÓN}

Stiglitz (1) explica que la hidrólisis alcalina se manifiesta por la formación de unas manchas de color oscuro en la superficie seguido de un agrietamiento superficial y descascarillamiento. Por debajo de la capa superficial, el hormigón de cemento aluminoso es pastoso; inicialmente se trata de un espesor muy pequeño pero éste aumenta con el tiempo. Esta masa reblandecida de mortero esta salpicada por pequeños puntos blancos. Posteriormente, la superficie se recubre de un depósito blanquecino.

\section{INTRODUCTION}

Stiglitz (1) explains that this phenomenon is manifested by the formation of some dark stains in the surface followed by a superficial cracking and stripping off. Under the superficial layer, the cement mortar is soft, and at first it is not considered very thick but increases with time. This softened mortar is splashed by small white points. Later, the surface is covered by whitish deposit. 
Rengade, L'Hopitallier y Fontmagne (2) apuntan hacia un conjunto simultáneo de factores para que estas alteraciones se produzcan; porosidad del hormigón o del mortero, presencia de álcalis solubles, de agua y acceso del $\mathrm{CO}_{2}$ atmosférico. Las reacciones que tendrían lugar en este proceso se esquematizan de la forma siguiente:
Rengade, L'Hopitallier and Fontmagne (2) conclude toward a set of simultaneous factors as the cause for these alterations to be produced: porosity of the cement or of the mortar, presence of soluble alkalis, water and access of the atmospherical $\mathrm{CO}_{2}$. The reactions that take place in this process are expressed in the following form.

$$
\begin{gathered}
2 \mathrm{KOH}+\mathrm{CO}_{2} \rightarrow \mathrm{K}_{2} \mathrm{CO}_{3}+\mathrm{H}_{2} \mathrm{O} \\
\mathrm{mCaO} \cdot \mathrm{Al}_{2} \mathrm{O}_{3} \cdot \mathrm{nH}_{2} \mathrm{O}+\mathrm{mK}_{2} \mathrm{CO}_{3} \longrightarrow \mathrm{mCaCO}_{3}+2 \mathrm{~K}_{2} \mathrm{O} \cdot \mathrm{Al}_{2} \mathrm{O}_{3}+(2 \mathrm{~m}-2) \mathrm{KOH}+(\mathrm{n}-\mathrm{m}+1) \mathrm{H}_{2} \mathrm{O} \\
\mathrm{K}_{2} \mathrm{O} \cdot \mathrm{Al}_{2} \mathrm{O}_{3}+4 \mathrm{H}_{2} \mathrm{O} \rightarrow \mathrm{Al}_{2} \mathrm{O}_{3} \cdot 3 \mathrm{H}_{2} \mathrm{O}+2 \mathrm{KOH}
\end{gathered}
$$

De este modo se produce la regeneración del hidróxido alcalino que es nuevamente susceptible de carbonatación y, por tanto, de producir la descomposición de otras fases de aluminatos de calcio. De forma general se puede expresar,
The alkaline hydroxide is regenerated and it is again susceptible of carbonation producing the decomposition of other calcium aluminate phases. In a general form it can be expressed,

$$
\mathrm{m} \mathrm{CaO} \cdot \mathrm{Al}_{2} \mathrm{O}_{3} \cdot \mathrm{nH}_{2} \mathrm{O}+\mathrm{mCO}_{2} \longrightarrow \mathrm{mCaCO}_{3}+\mathrm{Al}_{2} \mathrm{O}_{3} \cdot 3 \mathrm{H}_{2} \mathrm{O}+(\mathrm{n}-3) \mathrm{H}_{2} \mathrm{O}
$$

es decir, los álcalis solamente intervienen en el proceso actuando de forma semejante a un catalizador.

Lafuma (3) asegura que este tipo de degradación puede tener lugar incluso en hormigones de adecuada calidad cuando los áridos contienen álcalis solubles como puede ser el caso del granito. Además, este autor sugiere que la presencia de álcalis promueve la conversión del $\mathrm{CAH}_{10} \mathrm{a} \mathrm{C}_{3} \mathrm{AH}_{6}$ y $\mathrm{AH}_{3}$. Duriez (4) asegura que este tipo de degradación puede no ser reconocido fácilmente mediante un simple estudio exterior. Este deterioro se produce únicamente cuando el hormigón de cemento aluminoso es poroso: el carbonato alcalino, viaja a través del hormigón, concentrándose por acción de capilaridad en la superficie, donde, además, se reconcentra por evaporación y da lugar a mayor carbonatación.

Brocard (5) realiza trabajos en los que encuentra que pastas de cemento aluminoso, curadas a $20^{\circ} \mathrm{C}$ en disoluciones de $\mathrm{NaOH}$ y $\mathrm{KOH}$, pierden aproximadamente el $50 \%$ de su resistencia a los 28 días y la fase principal, presente a esta edad, es el $\mathrm{C}_{3} \mathrm{AH}_{6}$. Midgley (6) apunta que la presencia de $\mathrm{K}_{2} \mathrm{CO}_{3}$ en pastas de cemento aluminoso acelera el proceso de conversión y, por consiguiente, la pérdida de resistencia.

Dunster, A. M., Crammond, N. J. (7) estudian edificios construidos durante los años 60 en los que se sospecha ha sucedido el proceso de hidrólisis alcalina con carbonatación, aseguran que la formación de hidróxido de aluminio con microestructura en forma de aguja es producto del proceso de hidrólisis alcalina. Sin so the alkalis only intervene in the process in similar form to a catalyst.

Lafuma (3) assures that this type of degradation can take place even in concrete of adequate quality when the arid contains soluble alkalis as can be the case of the granite. Moreover, this author suggests that the alkali presence promotes the conversion of $\mathrm{CAH}_{10}$ to $\mathrm{C}_{3} \mathrm{AH}_{6}$ and $\mathrm{AH}_{3}$. Duriez (4) assures that this type of degradation can't be easily recognised through a simple external study. This deterioration is produced solely when the aluminous cement concrete is porous: so the alkaline carbonate travels through concrete, being concentrated by capillarity action in the surface, where moreover is reconcentrated by evaporation giving greater carbonation.

Brocard (5) developed works in which he finds that aluminous cement pastes, cured at $20^{\circ} \mathrm{C}$ in $\mathrm{NaOH}$ and $\mathrm{KOH}$ dissolutions, loose approximately $50 \%$ of the strength at 28 days and the principal phase, present at this time, is $\mathrm{C}_{3} \mathrm{AH}_{6}$. Midgley (6) notes that the presence of $\mathrm{K}_{2} \mathrm{CO}_{3}$ in aluminous cement pastes accelerates the conversion process and consequently a previous and greater loss of strength.

Dunster, A. M., Crammond, N. J. (7) studing buildings built during the sixties, under suspicion of having suffered the process of alkaline hydrolysis with carbonation, assure that the formation of aluminium hydroxide in needle form is a product of the alkaline hydrolysis process. However, Scrivener, 
embargo, Scrivener, K. L, Lewis, M., Houghton, J. (8) encuentran buen comportamiento de durabilidad en estructuras examinadas de edificios construidos durante los años 60.

En otros trabajos (9) se ha estudiado el comportamiento del cemento aluminoso hidratado y curado a diversas humedades relativas, a diferentes temperaturas, sometido a la acción de distintas concentraciones de $\mathrm{CO}_{2}$ y en presencia de $\mathrm{K}^{+}$en cantidades inferiores al $0,05 \%$ de $\mathrm{K}_{2} \mathrm{O}$. Los resultados obtenidos informaron sobre interesantes aspectos de la evolución de las fases hidratadas y la influencia del $\mathrm{CO}_{2} \mathrm{y}$ del $\mathrm{K}^{+}$en dicho proceso, sin embargo, en ningún caso se observó un efecto que pudiera ser asimilado a la hidrólisis alcalina.

Como continuación de estos trabajos se han realizado otros estudios de carbonatación de este cemento en presencia de una proporción más elevada de $\mathrm{K}^{+} \mathrm{y}$ de $\mathrm{Na}^{+}(10)$. En estos estudios se alcanza una explicación de la carbonatación alcalina o "hidrólisis alcalina" del cemento aluminoso como consecuencia de la generación de un compuesto que se forma en determinadas y excepcionales circunstancias. Tras diversos estudios de síntesis y caracterización de éste compuesto (11) se considera que éste presenta una fórmula cercana a $\mathrm{K}_{4} \mathrm{Al}_{6}\left(\mathrm{CO}_{3}\right)_{11-x}(\mathrm{OH})_{2 x}\left(\mathrm{H}_{2} \mathrm{O}\right)_{y}$.

El presente trabajo tiene como objetivo dar cuenta de las condiciones de formación de este compuesto en probetas de cemento así como de su caracterización microestructural realizada mediante Microscopia Electrónica (SEM). Se realiza, asimismo, un estudio de ese compuesto a través de DRX y de espectroscopia infrarroja por Transformada de Fourier.

\section{EXPERIMENTAL}

Se elaboraron probetas prismáticas, de dimensiones $1 \times 1 \times 6 \mathrm{~cm}$, de cemento aluminoso $\left(\% \mathrm{SiO}_{2} 3,89, \% \mathrm{Al}_{2} \mathrm{O}_{3}\right.$ $\left.40,60, \% \mathrm{Fe}_{2} \mathrm{O}_{3} 15,84, \% \mathrm{CaO} 41,21\right)$ con disolución de $\mathrm{KOH}$, siendo el porcentaje de $\mathrm{K}_{2} \mathrm{O}$ en las probetas del $2 \%$. La temperatura de amasado de las pastas fue de $4^{\circ} \mathrm{C}$ y la relación disolución/cemento empleada de 0,8 .

Posteriormente, y como consecuencia de los resultados obtenidos en el estudio de estas probetas, se repitieron los ensayos utilizando un $6 \%$ de $_{2} \mathrm{O}$.

\subsection{Curado de las probetas}

Las probetas se curaron durante 7 días a $4^{\circ} \mathrm{C}$ y H.R del $100 \%$ y durante otros 7 días a la misma temperatura y a H.R. del $75 \%$. Se estudió la composición mineralógica de estas probetas mediante DRX y FTIR.
K. L, Lewis, M., Houghton, J. (8) find good permanent behaviour in examined building structures built during the sixties.

In previous papers (9) have studied the behaviour of hydrated aluminous cement cured at different relative humidities, temperatures, submitted to different $\mathrm{CO}_{2}$ concentrations and in presence of $\mathrm{K}^{+}$ always below $0,05 \% \mathrm{~K}_{2} \mathrm{O}$. The obtained results informed of interesting aspects about the evolution of hydrated phases and the influence of $\mathrm{CO}_{2}$ and potassium in this process; however, an effect that could be assimilated to the alkaline hydrolysis was not observed.

As continuation of these works others have been developed regarding carbonation of this cement in presence of higher proportions of $\mathrm{K}^{+}$and $\mathrm{Na}^{+}(10)$. In these studies an explanation of alkaline carbonation or "alkaline hydrolysis" of aluminous cement is reached as consequence of the generation of a compound that is formed in exceptional circumstances. After synthesis and characterisation studies of this compound (11) it is considered that its formula is close to $\mathrm{K}_{4} \mathrm{Al}_{6}\left(\mathrm{CO}_{3}\right)_{11-x}(\mathrm{OH})_{2 x}\left(\mathrm{H}_{2} \mathrm{O}\right)_{y}$

The present paper informs about the formation conditions of this aluminium potassium carbonate hydrate in aluminous cement mortars as well as its microstructural characterisation through Electronic Microscopy (SEM). It is also a study through XRD and Fourier Transform infrared spectroscopy.

\section{EXPERIMENTAL}

Prismatic specimens, $1 \times 1 \times 6 \mathrm{~cm}$, of aluminous cement $\left(\% \mathrm{SiO}_{2} 3,89, \% \mathrm{Al}_{2} \mathrm{O}_{3} 40,60, \% \mathrm{Fe}_{2} \mathrm{O}_{3} 15,84, \% \mathrm{CaO} 41,21\right)$ were prepared. The solution/cement ratio used was 0.8 and the mixing temperature of the pastes was $4{ }^{\circ} \mathrm{C}$. The potassium content of the specimens was $2 \%$ wt. of $\mathrm{K}_{2} \mathrm{O}$.

As a consequence of the results obtained in the study of these specimens, new specimens were repeated with $6 \%$ of $\mathrm{K}_{2} \mathrm{O}$.

\subsection{Specimens curing}

The specimens were cured during 7 days at $4{ }^{\circ} \mathrm{C}$ and $100 \%$ R.H; during next 7 days were submitted to the same temperature and an environment of $75 \%$ R.H. The mineralogical characterisation of these samples were carried out through XRD and FTIR. 


\subsection{Carbonatación de las probetas}

Las probetas, tras los 14 días de curado, se sometieron a un proceso de carbonatación acelerada, a temperatura ambiente $\left(20^{\circ} \mathrm{C}\right)$. En las cámaras de carbonatación la humedad relativa permaneció al $75 \%$ y el ambiente estaba saturado de $\mathrm{CO}_{2}$.

Transcurridos 2 y 6 meses de carbonatación en las condiciones descritas, se realizaron ensayos de caracterización mineralógica a través de DRX, FTIR y microestructural mediante SEM en la parte externa $\mathrm{e}$ interna de las probetas (12), aunque en este trabajo únicamente se describen los resultados obtenidos de la región externa de las probetas dado que es, en esta zona, donde se produce mayor formación del carbonato de aluminio y potasio.

\section{RESULTADOS}

\subsection{Difracción de Rayos X}

\subsubsection{Probetas $2 \% \mathrm{~K}_{2} \mathrm{O}$}

Mediante el análisis de los difractogramas de las muestras sin carbonatar y carbonatadas durante dos y seis meses puede comprobarse que el $\mathrm{CAH}_{10} \mathrm{y} \mathrm{C}_{3} \mathrm{AH}_{6}$ producidos en la hidratación, se carbonatan casi totalmente a los dos meses de carbonatación, para dar lugar a la formación de carbonato cálcico e hidróxido de aluminio. En lo que respecta al carbonato cálcico, se producen sus tres polimorfías, calcita, aragonito y vaterita. En cuanto al hidróxido de aluminio, se encuentra en forma de gibbsita, bayerita y nordstrandita; la gibsita se forma directamente junto al $\mathrm{C}_{3} \mathrm{AH}_{6}$, sin embargo la nordstrandita y bayerita son productos de la carbonatación.

A los seis meses de carbonatación no se encuentran, mediante esta técnica, claras diferencias con respecto a los compuestos cristalinos detectados a dos meses de carbonatación.

Estos difractogramas presentan una línea de reflexión en $2 \theta: 35,65^{\circ}$ demasiado intensa para corresponder solamente al aluminato monocálcico anhidro, por tanto la asignación de esta reflexión es dudosa.

\subsubsection{Probetas $6 \% \mathrm{~K}_{2} \mathrm{O}$}

Mediante el análisis de los difractogramas de la probeta sin carbonatar y de la región exterior de las probetas carbonatadas durante dos meses y seis meses, se comprueba que, tras dos meses de carbonatación, el $\mathrm{C}_{3} \mathrm{AH}_{6}$ reacciona totalmente con el $\mathrm{CO}_{2}$. Se forman las tres polimorfias de carbonato cálcico. La vaterita es la

\subsection{Specimens carbonation}

The specimens were submitted to an accelerated process of carbonation, after 14 days of being cured, at ambient temperature $\left(20^{\circ} \mathrm{C}\right)$. In the carbonation chambers the relative humidity stayed at $75 \%$ and the environment was saturated with $\mathrm{CO}_{2}$.

After two and six months of carbonation in the conditions described, test of mineralogical characterisation in the internal and external parts of specimens were carried out by XRD, FTIR and a microstructural study of both regions were developed through SEM (12). The aim of this paper is to relate only the obtained results from the external region of the specimens since it is the zone where greater aluminium potassium carbonate hydrate is produced.

\section{RESULTS}

\subsection{Ray Diffraction}

\subsection{1. $2 \% \mathrm{~K}_{2} \mathrm{O}$ specimens}

$X R D$ spectra of non-carbonated and carbonated samples during two and six months show that the $C A H_{10}$ and $C_{3} A H_{6}$ produced in hydration are almost completely carbonated at two months of carbonation time, to give place to calcium carbonate and aluminium hydroxide. The three calcium carbonate polymorphs are produced, calcite, aragonite and vaterite. Regarding the aluminium hydroxide gibbsite, bayerite and nordstrandite are formed; the gibbsite is formed directly together with $\mathrm{C}_{3} \mathrm{AH}_{6}$, in hydration process, however nordstrandite and bayerite are carbonation products.

At six carbonation months no great differences were found with respect to crystalline compounds detected at two carbonation months by DRX.

These diffractograms present a reflection line at $2 \theta: 35.65^{\circ}$ too intense to correspond only to anhydrous calcium aluminate, so the assignment of this reflection line is not clear.

\subsection{2. $6 \% \mathrm{~K}_{2} \mathrm{O}$ specimens}

DRX spectra of non-carbonated and carbonated samples during two and six months show that after two carbonation months $C_{3} A H_{6}$ reacts completely with $\mathrm{CO}_{2}$. The three calcium carbonate polymorphs are formed, vaterite is the mainly polymorph formed, followed by calcite and aragonite. At six carbonation 
fase carbonatada principalmente formada, en segundo lugar, la calcita y, en último lugar, el aragonito. A los seis meses de carbonatación únicamente se observa una mayor proporción del carbonato cálcico en forma de calcita.

En lo que respecta al hidróxido de aluminio, se encuentra, principalmente, en forma de nordstrandita, aunque también hay bayerita y gibbsita, en menor proporción.

Se detectan líneas de reflexión en $2 \theta: 15,95^{\circ}$ y $35,65^{\circ}$, siendo, ésta última, de mayor intensidad que en las probetas amasadas con $2 \%$ de $\mathrm{K}_{2} \mathrm{O}$. Estas líneas son originadas por la presencia en las muestras de un carbonato de aluminio y potasio hidratado. Las líneas de reflexión de dicha fase son relativamente anchas, lo que podría indicar una baja cristalinidad de este compuesto.

\subsection{Espectroscopía de absorción IR}

\subsubsection{Probetas $2 \% \mathrm{~K}_{2} \mathrm{O}$}

Los espectros IR de la zona exterior de las probetas carbonatadas durante dos y seis meses se presentan en la figura 1. Como puede verse en dicha figura, en la región del espectro comprendida entre $4.000-3.000 \mathrm{~cm}^{-1}$, del espectro de la muestra carbonatada durante dos meses, solamente presenta una banda ancha centrada en torno a $3.430 \mathrm{~cm}^{-1}$. Esta banda no se corresponde con ninguna de las vibraciones producidas por los compuestos característicos de hidratación y carbonatación del cemento aluminoso.

El espectro IR de la muestra carbonatada dos meses, presenta dos bandas anchas mutuamente solapadas con máximos hacia $1.485 \mathrm{~cm}^{-1}$ y $1.414 \mathrm{~cm}^{-1}$ y un hombro hacia $1.525 \mathrm{~cm}^{-1}$ debidas a vibraciones de tipo $v_{3}$. Hay una banda de vibración tipo $v$, en $1.090 \mathrm{~cm}^{-1}$; además se encuentran dos bandas de tipo $v_{2}$ en $880 \mathrm{~cm}^{-1}$ y 855 $\mathrm{cm}^{-1} \mathrm{y}$ otras bandas de tipo $v_{4}$ en $760 \mathrm{~cm}^{-1}, 740 \mathrm{~cm}^{-1} \mathrm{y}$ $715 \mathrm{~cm}^{-1}$, todas ellas debidas a vibraciones de grupos $\mathrm{CO}_{3}{ }^{2-}$. Se confirma la presencia de carbonato cálcico en forma de calcita, aragonito y vaterita. Además de un compuesto carbonatado distinto a los generalmente observados en la carbonatación de este material (13).

A frecuencias menores, presenta una banda en $1.005 \mathrm{~cm}^{-1}$ producida por tensión $\mathrm{Al}-\mathrm{OH}$ mientras que hacia $635 \mathrm{~cm}^{-1}, 510 \mathrm{~cm}^{-1}$ y $470 \mathrm{~cm}^{-1}$ son vibraciones originadas por grupos $\mathrm{AlO}_{6}$. Todas estas bandas se asignan a un carbonato de aluminio y potasio hidratado.

En el espectro IR de la muestra carbonatada durante 6 meses puede comprobarse una cierta evolución de la months a greater proportion of calcite polymorph is observed.

With respect to the aluminium hydroxide, nordstrandite is mainly formed, although bayerite and gibbsite are also present in lower proportion

Reflection lines at $2 \theta: 15.95^{\circ}$ and $35.65^{\circ}$ are detected, the later has higher intensity than that of the specimens with $2 \% \mathrm{~K}_{2} \mathrm{O}$. These reflection lines are originated by the presence in the samples of the aluminium potassium carbonate hydrate. Reflection lines of that phase are relatively broad, this may indicate a low crystallinity of this compound.

\subsection{Infrared spectroscopy}

\subsection{1. $2 \% \mathrm{~K}_{2} \mathrm{O}$ specimens}

The IR spectra of the external region of two and six carbonated months specimens are presented in figure 1. In 4.000-3.000 $\mathrm{cm}^{-1}$ spectral-region, only a broad absorption band in $3.430 \mathrm{~cm}^{-1}$ is shown in the two carbonated months in spectra. This band does not correspond with typical vibrations produced by vibrational groups of the hydration and carbonation compounds of this cement.

In the $\mathrm{CO}_{3}^{2-}$ group vibrations region, the two carbonated months spectrum show $v_{3}$ type vibrations, that is, two broad bands overlapped with about $1.485 \mathrm{~cm}^{-1}$ and $1.414 \mathrm{~cm}^{-1}$ maximum and $a$ shoulder near $1.525 \mathrm{~cm}^{-1}, v_{1}$ type vibrations in 1.090 $\mathrm{cm}^{-1}, v_{2}$ in $880 \mathrm{~cm}^{-1}$ and $855 \mathrm{~cm}^{-1}$ and $v_{4}$ type in 760 $\mathrm{cm}^{-1}, 740 \mathrm{~cm}^{-1}$ and $715 \mathrm{~cm}^{-1}$. These absorption bands confirm the presence of calcite, aragonite and vaterite joint to a carbonated compound different from those studied traditionally in the carbonation of this material (13).

At lower frequencies, the IR spectra presents an absorption band in $1.005 \mathrm{~cm}^{-1}$ produced by tension vibration Al-OH and near $635 \mathrm{~cm}^{-1}, 510 \mathrm{~cm}^{-1}$ and $470 \mathrm{~cm}^{-1}$ originated by $\mathrm{AlO}_{6}$ groups. All these bands are assigned to aluminium potassium carbonate hydrate.

The IR spectrum of six carbonated months sample shows a certain evolution of the sample to the formation of 


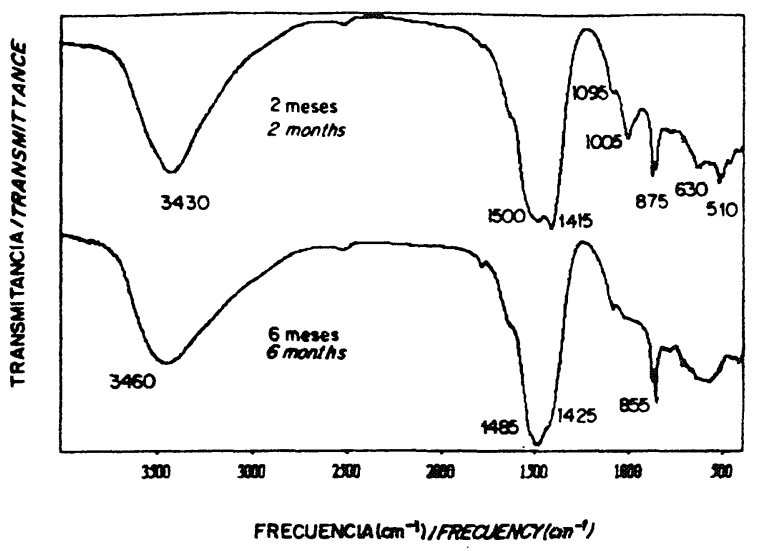

Figura 1.- Probetas $2 \% \mathrm{~K}_{2} \mathrm{O}$.

Figure 1.- Specimens $2 \% \mathrm{~K}_{2} \mathrm{O}$.

muestra hacia la formación de carbonatos cálcicos en forma de aragonito principalmente y de calcita.

\subsubsection{Probetas $6 \% \mathrm{~K}_{2} \mathrm{O}$}

Los espectros de IR de la parte exterior de las probetas carbonatadas durante dos y seis meses, como pueden verse en la figura 2, son prácticamente idénticos. En la región de 4.000-3.000 $\mathrm{cm}^{-1}$ hay una banda ancha de absorción centrada en $3.430 \mathrm{~cm}^{-1}$ y que es producida, principalmente, por los grupos $\mathrm{OH}$ del carbonato de aluminio y potasio hidratado.

Las vibraciones originadas por grupos $\mathrm{CO}_{3}{ }^{2-}$ de este compuesto aparecen en torno a $1.525 \mathrm{~cm}^{-1}\left(v_{3}\right)$, $1.415 \mathrm{~cm}^{-1}\left(v_{3}\right), 1.095 \mathrm{~cm}^{-1}\left(v_{1}\right), 875 \mathrm{~cm}^{-1}\left(v_{2}\right), 745$ $\mathrm{cm}^{-1}\left(v_{4}\right)$. Hay una banda, también de grupos $\mathrm{CO}_{3}^{2-}$, en $715 \mathrm{~cm}^{-1}\left(v_{4}\right)$ que indica la presencia minoritaria de carbonato calcico.

A frecuencias menores se encuentra una banda originada por la vibraciones de tensión Al-OH en $1.005 \mathrm{~cm}^{-1}$. Bandas de absorción en $630 \mathrm{~cm}^{-1}$ y $510 \mathrm{~cm}^{-1}$ son producidas por los distintos grupos $\mathrm{AlO}_{6}$ del compuesto carbonatado de aluminio y potasio.

\subsection{Microscopia electrónica (SEM)}

En la caracterización de este compuesto mediante SEM, se encuentra que éste presenta una microestructura, de muy pequeñas dimensiones, en forma de "granulitos" cuyo análisis mediante EDX (Figura 3) sólo manifiesta la presencia de aluminio y potasio. En la fotografia 1 puede verse dicho compuesto y puede comprobarse su evolución. La zona marcada con "A" en la foto se trata de morfologías con poco desarrollo microestructural sobre las que hay microcristales; el análisis de estas zonas indica que se trata de aquella fase constituida únicamente por aluminio y potasio. Estas microestructuras encuentran

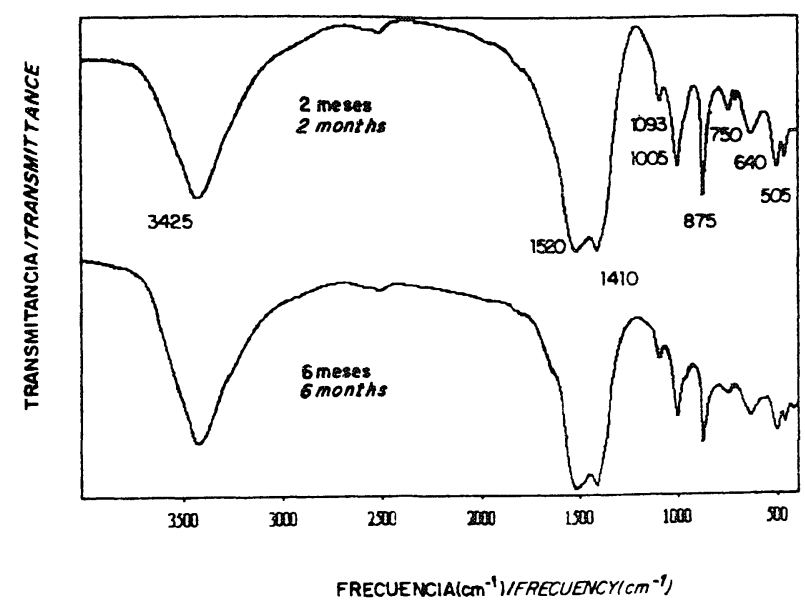

Figura 2.- Probetas $6 \% \mathrm{~K}_{2} \mathrm{O}$.

Figure 2.- Specimens $6 \% \mathrm{~K}_{2} \mathrm{O}$.

calcium carbonate mainly in aragonite form and in calcite form.

\subsection{2. $6 \% \mathrm{~K}_{2} \mathrm{O}$ specimens}

The IR spectra of the external region of two and six carbonated months specimens are presented in figure 2. Both IR spectra are similar. In 4.000-3.000 $\mathrm{cm}^{-1}$ spectral region, there is a broad absorption band at $3.430 \mathrm{~cm}^{-1}$ originated by the $\mathrm{OH}$ groups of aluminium potassium carbonate hydrate.

The vibrations originated by $\mathrm{CO}_{3}^{2-}$ groups of this compound appear at $1.525 \mathrm{~cm}^{-1}\left(v_{3}\right), 1.415 \mathrm{~cm}^{-1}\left(v_{3}\right)$, $1.095 \mathrm{~cm}^{-1}\left(v_{1}\right), 875 \mathrm{~cm}^{-1}\left(v_{2}\right), 745 \mathrm{~cm}^{-1}\left(v_{4}\right) . A n$ absorption band in $715 \mathrm{~cm}^{-1}\left(v_{4}\right)$, also $\mathrm{CO}_{3}^{2-}$ groups, indicates the minor presence of calcium carbonate.

At lower frequencies, an absorption band originated by $\mathrm{Al}-\mathrm{OH}$ tension vibrations appears in $1.005 \mathrm{~cm}^{-1}$. Absorption bands in $630 \mathrm{~cm}^{-1}$ and $510 \mathrm{~cm}^{-1}$ are produced by $\mathrm{AlO}_{6}$ groups of aluminium potassium carbonate hydroxide-hydrate.

\section{3.- Electronic microscopy (SEM)}

The SEM characterisation of this compound shows very small crystals, which morphology is in fibber form and whose EDX microanalysis (Figure 3) indicates $\mathrm{Ca}$ absence and aluminium and potassium presence. In picture 1 can be seen this compound and the evolution of this phase can be confirmed. The region marked with " $A$ " in the picture corresponds to little developed morphologies with microcrystals above; the analysis of these regions indicates that this is phase constituted only by Al and K. These microstructures find continuity in the film-gel 


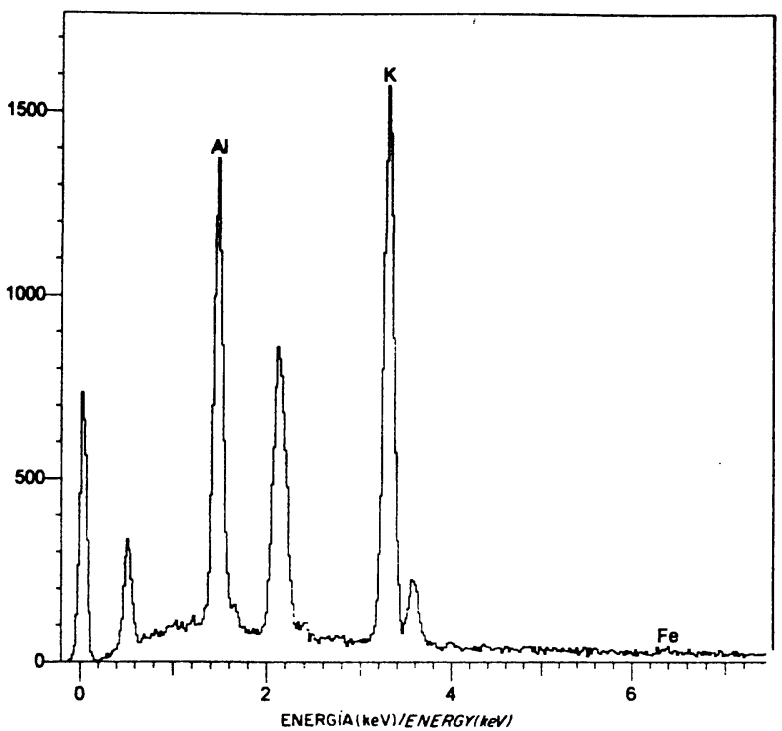

Figura 3.- Análisis mediante EDX.

Figure 3.- EDX analysis.

continuidad en una película -especie de gel-, marcado con " $\mathrm{B}$ " en la foto, cuyo análisis muestra que contiene calcio, aluminio y potasio. Se trata, por tanto, de una especie intermedia en evolución. En algunas zonas, marcadas con " $C$ " en la foto, esa película se separa y su análisis indica que esta constituida fundamentalmente por calcio. Próximo a estas regiones se observa la posible formación de aristas de los futuros cristales de $\mathrm{CaCO}_{3}$.

\section{DISCUSIÓN Y CONCLUSIONES}

En el presente trabajo se demuestra la formación, en las muestras estudiadas, de un compuesto cuya fórmula es cercana a $\mathrm{K}_{4} \mathrm{Al}_{6}\left(\mathrm{CO}_{3}\right)_{11-x}(\mathrm{OH})_{2 x}\left(\mathrm{H}_{2} \mathrm{O}\right)_{y}$.

El empleo de la técnica de difracción de rayos x para el estudio de dicho compuesto puede ser algo complejo puesto que gran parte de sus líneas de reflexión son coincidentes con las del cemento aluminoso anhidro así como con las de sus productos de carbonatación.

Debe ser considerado, además, que este compuesto se encuentra mayoritariamente en la zona superficial de las probetas, por tanto un estudio medio de la composición mineralógica del material conlleva una "dilución" importante de este compuesto dentro de la muestra y, como consecuencia, se produce una disminución de la intensidad relativa de sus líneas de reflexión con respecto a la de otros constituyentes, este hecho haría difícil o imposible su identificación, aun cuando son utilizadas elevadas concentraciones de álcali. Por tanto, es probable que el estudio de la formación de este compuesto en la carbonatación del cemento aluminoso en presencia de una concentración menor de álcalis no pueda ser detectada mediante DRX.

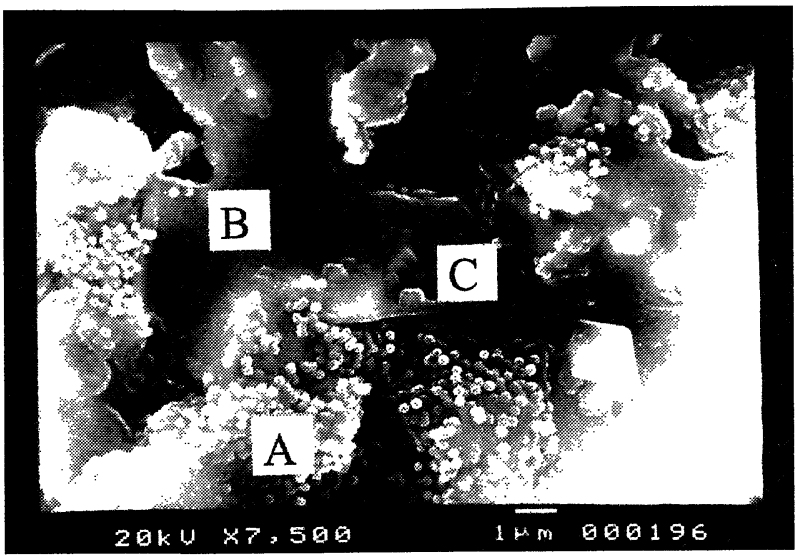

Foto 1.- Carbonato de aluminio y potasio.

Photo 1.- Aluminium potassium carbonate.

specie- marked with a " $B$ " in the picture, whose analysis shows its content in $\mathrm{Ca}, \mathrm{Al}$ and $\mathrm{K}$. Thus, it corresponds to an intermediate specie in evolution. In some regions, marked with a " $C$ " in the picture, the film is separated and its analysis shows that it is mainly constituted by calcium. Close to these regions, the possible formation of the edges of future calcium carbonate crystals are observed.

\section{DISCUSSION AND CONCLUSIONS}

In this work, the formation of a compound which formula is close to $\mathrm{K}_{4} \mathrm{Al}_{6}\left(\mathrm{CO}_{3}\right)_{11-x}(\mathrm{OH})_{2 \mathrm{x}}\left(\mathrm{H}_{2} \mathrm{O}\right)_{y}$ is shown, in the studies samples.

$X$ ray diffraction technique used in the study can be something complex, most part of its reflection lines are coincident with those of the anhydrous aluminous cement as well as with those of its carbonation products.

It must be considered, moreover, that this compound is found more in the superficial zone of the specimens, so an average study of the mineralogical material composition shares an important "dilution" of this compound within the other components of the sample and as consequence a decrease is produced of the relative intensity of its reflection lines with respect to the other reflection lines. This fact would make difficult or impossible its identification, even if high alkali concentrations are used. For this reason, it is possible that in the study of the aluminium potassium carbonate hydrate formation in aluminous cement carbonation in smaller alkali concentrations its presence could not be detected by XRD. 
Es de gran ayuda para el estudio de la formación de este compuesto en la carbonatación del cemento aluminoso el empleo de la técnica de espectroscopia de absorción IR. Dicha técnica es de gran sensibilidad a los compuestos carbonatados $\mathrm{y}$, por tanto, también al carbonato de aluminio y potasio hidratado.

La carbonatación del cemento aluminoso en presencia de álcalis, y más concretamente para el caso estudiado en presencia de potasio, tiene lugar al menos en dos etapas. Una primera etapa en la que se produce la evolución de los aluminatos de calcio hidratados hacía la formación de carbonato de aluminio y potasio hidratado y carbonato cálcico, dicha etapa podría ser la siguiente:

$$
\mathrm{mCaO} \cdot \mathrm{Al}_{2} \mathrm{O}_{3} \cdot \mathrm{nH}_{2} \mathrm{O} \quad \mathrm{CO}_{2}, \mathrm{~K}^{+}, \mathrm{H}_{2} \mathrm{O}
$$

En el estudio realizado por SEM se pone de manifiesto que pueden coexistir distintas especies químicas, como consecuencia de la carbonatación, que presentan composiciones variables en calcio, aluminio y potasio. En una etapa posterior, dicho carbonato de aluminio y potasio hidratado evolucionaría hacia la formación de hidróxido de aluminio, inicialmente en fase amorfa.

De forma general se podría expresar,

$$
\mathrm{mCaO} \cdot \mathrm{Al}_{2} \mathrm{O}_{3} \cdot \mathrm{nH}_{2} \mathrm{O} \stackrel{\mathrm{CO}_{2}, \mathrm{~K}^{+}, \mathrm{H}_{2} \mathrm{O}}{\longrightarrow}
$$

Diversos factores tienen una gran influencia en este proceso de carbonatación, tales como la porosidad del material, la humedad relativa, la concentración de $\mathrm{CO}_{2}$, la temperatura y, por descontado, es necesaria la presencia de álcalis en el medio.

\section{AGRADECIMIENTOS}

Los autores del presente trabajo desean mostrar su agradecimiento a la CICIT por la subvención concedida al Proyecto MAT98-0792. Así como también a Esperanza Menéndez, del servicio de Análisis y Ensayos del Instituto de Ciencias de la Construcción Eduardo Torroja (CSIC) por la colaboración en la aplicación de la Microscopía Electrónica de Barrido.
It is helpful for the study of this compound in the aluminous cement carbonation the use of infrared absorption spectroscopy IR. This technique is of great sensibility to the carbonated compounds so also to the aluminium potassium carbonate hydrate.

The aluminous cement carbonation in alkali presence, and specifically for potassium presence, takes place at least in two stages. In a first stage, in which the evolution of the calcium aluminate hydrates toward the formation of aluminium potassium carbonate hydrate and calcium carbonate is produced. Such a stage could be the following:

$$
\mathrm{K}_{4} \mathrm{Al}_{6}\left(\mathrm{CO}_{3}\right)_{11-x}(\mathrm{OH})_{2 x}\left(\mathrm{H}_{2} \mathrm{O}\right)_{y}+\mathrm{CaCO}_{3}
$$

SEM study shows that different chemical phases with variable calcium, aluminium and potassium compositions can coexist as a consequence of the carbonation process. In a subsequent stage, that aluminium potassium carbonate hydrate suffers a gradual development toward the aluminium hydroxide formation, mainly in amorphous phase.

In general, it can be expressed,

$$
\mathrm{mCaCO}_{3}+\mathrm{Al}(\mathrm{OH})_{3}+\mathrm{K}_{2} \mathrm{CO}_{3} \cdot \mathrm{H}_{2} \mathrm{O}
$$

Several factors that have great influence in this carbonation processes should be considered, such as the porosity of the material, the relative humidity, the $\mathrm{CO}_{2}$ concentration, the temperature and without doubt the necessary presence of alkalis.

\section{ACKNOWLEDGMENTS}

The authors of the present paper wish to thank to the CICYT for founding this research through the project MAT98-0792. Thanks also to Esperanza Menéndez, from the Análisis y Ensayos Service of the Instituto de Ciencias de la Construcción Eduardo Torroja (CSIC), for the collaboration in the Scanning Electronic Microscopy application.

\section{BIBLIOGRAFÍA}

(1) STIGLITZ, P.: Reveue des Matériaux de Construction, nº 671-672, 219(1970).

(2) RENGADE, L.: 'Hopitallier, Fontmagne, Reveue des Matériaux de Construction, $\mathrm{n}^{\circ}$ 378-379(1936).

(3) LAFUMA, H.: Revue Genérale de Sciences Appliquées, Vol. 1, n³, pp. 66-74 (1952).

(4) DURIEZ, M.: Editions du Moniteur des Travaux Publics, Paris (1957). 
(5) BROCARD, J.: Compte Renau de L’Academie des Sciences, Vol. 233, n5, pp. 413-416 January (1951).

(6) MIDGLEY, H. G., MIDGLEY, A.: Magazine of Concrete Research, Vol. 27, n91. (1975).

(7) DUNSTER, A. M., CRAMMOND, N. J.: X Symposium International In The Chemistry of Cements, Gotheborg (1997).

(8) SCRIVENER, K.L., LEWIS, M., HOUGHTON, J.: X Symposium International In The Chemistry of Cements, Gotheborg (1997).

(9) PUERTAS, F., FERNÁNDEZ-CARRASCO, L., BLANCO-VARELA, M.T., VÁZQUEZ, T.: De La Fuente, A., Journal Materials Science 31,pp. 2819-2827(1996).

(10) FERNÁNDEZ-CARRASCO, L., PUERTAS, F., BLANCO-VARELA, M.T., VÁZQUEZ, T.: Remitido para su publicación a Cement and Concrete Research.

(11) FERNÁNDEZ-CARRASCO, L., PUERTAS, F., BLANCO-VARELA, M.T., VÁZQUEZ, T.: VI Reunión Nacional de Materiales. San Sebastian (1999).

(12) FERNÁNDEZ-CARRASCO, L., PUERTAS, F., BLANCO-VARELA, M.T., VÁZQUEZ, T.: Remitido para su publicación a Cement and Concrete Research.

(13) FERNÁNDEZ-CARRASCO, L., VÁZQUEZ, T.: Materiales de construcción, Vol. 46, n² 241, enero/febrero/marzo (1996).

\section{Publicación del Instituto Eduardo Torroja - CSIC}

\section{Número monográfico de INFORMES}

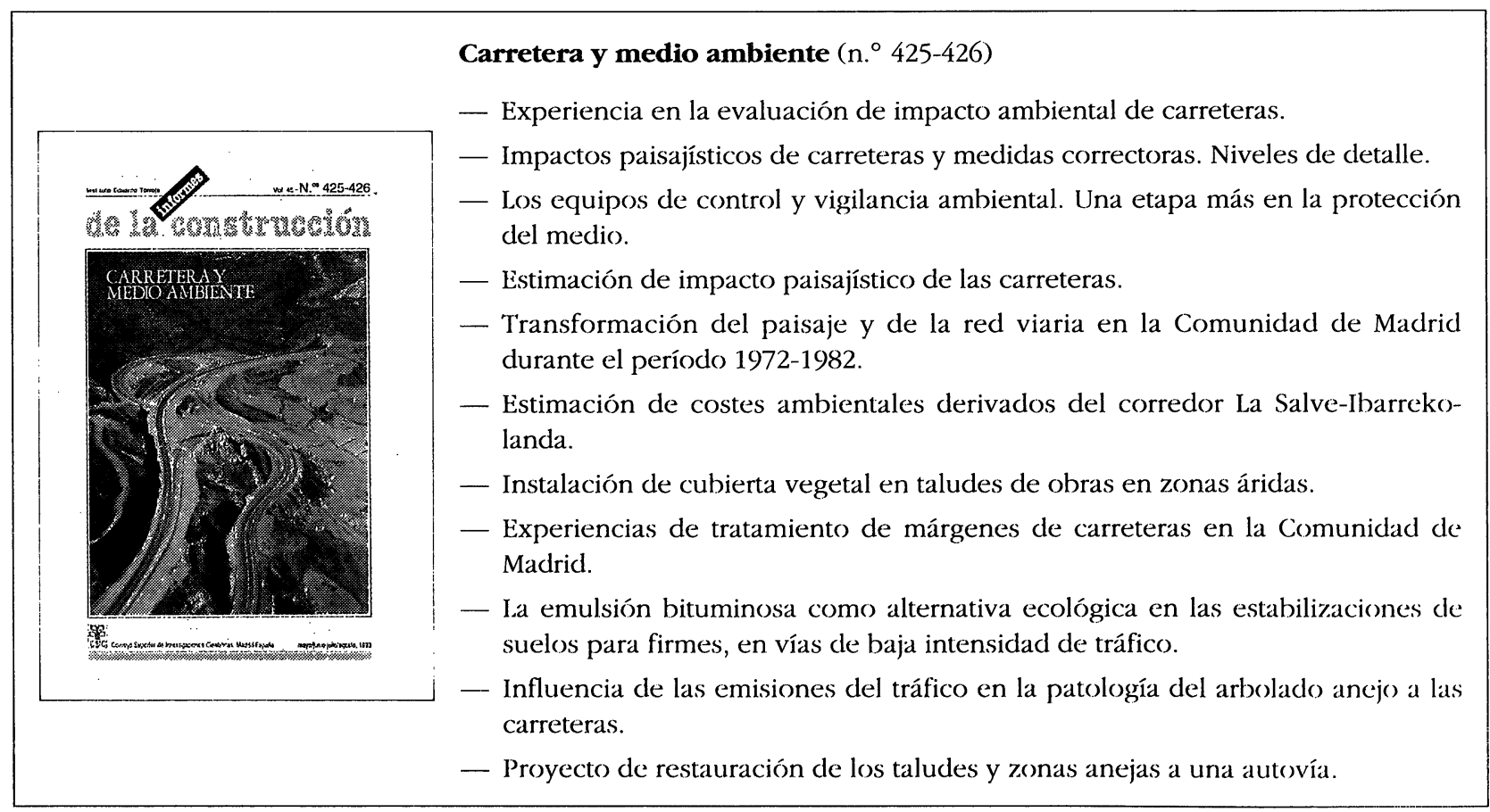

